\title{
Hubungan Tingkat Aktivitas Fisik, Jumlah Asupan Vitamin D dan Kalsium Terhadap Tingkat Densitas Tulang Remaja Putri di SMA Negeri Kecamatan Tilatang Kamang Kabupaten Agam
}

\author{
Desrida ${ }^{1}$, Afriwardi $^{2}$, Husnil Kadri ${ }^{3}$
}

\begin{abstract}
Abstrak
Kepadatan tulang yang rendah saat remaja dapat meningkatkan risiko terjadinya osteoporosis. Terdapat beberapa faktor yang mempengaruhi kepadatan tulang seperti asupan vitamin $D$, kalsium dan aktivitas fisik. Tujuan penelitian ini adalah menentukan hubungan aktivitas fisik, vitamin D dan kalsium terhadap kepadatan tulang pada remaja putri di SMA Negeri Tilatang Kamang. Desain penelitian adalah cross-sectional dengan subyek 148 remaja putri dipilih dengan metode simple random sampling. Data yang diambil adalah tingkat aktivitas fisik, asupan vit $D$, kalsium dan densitas tulang. Pemeriksaan densitas tulang dengan menggunakan alat Quantum Analizer. Jumlah asupan vitamin D dan kalsium menggunakan modifikasi FFQ masakan minang yang dirancang oleh Lipoeto. Tingkat aktivitas fisik diukur dengan menggunakan kuesioner Baecke. Analisis bivariat dengan menggunakan uji statistik ChiSquare dengan derajat kemaknaan $\alpha=0,05$. Persentase responden yang memiliki tingkat densitas tulang abnormal $51,4 \%$, tingkat aktivitas kurang aktif 50,7\% dan asupan kalsium kurang 52,7\%. Ada hubungan bermakna antara tingkat aktivitas fisik dengan tingkat densitas tulang remaja putri diperoleh nilai $p<0,05$. Hasil uji statistik yang didapatkan ada hubungan yang signifikan antara asupan vitamin $D$ dengan tingkat densitas tulang $p<0,05$. Ada hubungan bermakna antara asupan kalsium dengan tingkat densitas tulang remaja putri di peroleh nilai $p<0,05$. Simpulan penelitian ini adalah terdapat hubungan aktivitas fisik, asupan vit $D$ dan kalsium terhadapa tingkat densitas tulang.
\end{abstract}

Kata kunci: aktivitas fisik, vitamin D, kalsium, densitas tulang

\begin{abstract}
Low bone density during adolescence may increase the risk of osteoporosis. There are several factors that affect bone density among physical activity, vitamin $D$ and calcium. The objective of the study was to determine correlations of vitamin D intake, calsium intake and physical activity on bone density in female adolescent at SMAN Tilatang Kamang. Design of this study was cross-sectional on 148 female adolescent, selected by simple random sampling. The data were physical activity, vitamin $D$ intake, calcium intake and bone density score. Vitamin $D$ and calcium intake was examined with Minang cuisine FFQ modification by Lipoeto. Assessment of physical activity by Baecke questionaire. Bivariat analysis was using Chi-Square test significance level $\alpha=0.05$. Percentage respondents normal bone density $51.4 \%$, has moderate physical activity $50,7 \%$, and less intake calcium $52,7 \%$. There is significant correlation between physical activities to bone density $(p<0,05)$. Statistical examination showed significant correlation between vitamin $D$ intake to bone mineral level $(p<0,05)$. Calcium intake correlates to bone density of female adolescence $(p<0,05)$. The conclusion is a significant correlation between physical activity, vitamin $D$ and calcium on bone density.
\end{abstract}

Keywords: physical activity, vitamin D, calcium, and bone density

Affiliasi penulis : 1. Prodi Magister Biomedik FK Unand (Fakultas Kedokteran Universitas Padang), 2. Bagian Fisiologi FK Unand, 3. Bagian Biokimia FK Unand
Korespondensi: desrida@rocketmail.com/ bdesrida@gmail.comTelp: 081363373793 


\section{PENDAHULUAN}

Ada lebih dari 200 tulang membentuk kerangka penopang bagian tubuh yang disebut rangka. Pada umumnya terdapat 206 tulang didalam rangka.Tulang adalah organ keras dari semua jaringan dalam tubuh yang bersifat kuat dan kaku serta sulit dibengkokkan. ${ }^{1}$ Penurunan densitas massa tulang dan perburukan mikro arsitektur tulang sehingga tulang menjadi rapuh dan mudah patah disebut dengan penyakit tulang Osteoporosis. $^{2}$

Densitas tulang berbeda menurut umur, meningkat pada bagian pertama kehidupan dan menurun secara berangsur setelah dewasa. Massa puncak tulang dicapai pada awal usia 20 tahun dan terdapat bukti bahwa faktor-faktor seperti kurangnya latihan fisik, genetik, jenis kelamin, persyarafan, gaya hidup (kebiasaan merokok, konsumsi alkohol, fast food), asupan vitamin D dan kalsium yang buruk Pengaruh hormon (PTH, Tirokal sitonin, Growth Hormon, Tiroksin) memberikan pengaruh yang merugikan bagi massa mineral tulang. ${ }^{123}$

Aktivitas fisik adalah segala kegiatan atau aktivitas yang menyebabkan peningkatan penggunaan energy/kalori oleh tubuh. ${ }^{4}$ Perubahan tulang yang disebabkan oleh aktivitas fisik dapat meningkatkan enzim tulang dan pembesaran pada tulang (bone hypertrophy). Untuk pembentukan tulang baru diperlukan rangsangan terus menerus pada tulang, Tulang kita seperti otot perlu latihan supaya kuat. ${ }^{1}$ Kalsium merupakan mineral yang paling banyak terdapat dalam tubuh. Tubuh orang dewasa diperkirakan mengandung 1000 gram kalsium. Semakin tinggi kebutuhan dan semakin rendah persediaan kalsium dalam tubuh semakin efisien absorpsi kalsium. Penyerapan akan meningkat bila kalsium yang dikonsumsi menurun. Vitamin $D$ dan aktivitas fisik berpengaruh baik terhadap absorpsii kalsium. $^{5}$

Vitamin $D$ berfungsi dalam pertumbuhan tulang normal dan proses mineralisasi. Vitamin D juga mempengaruhi metabolisme kalsium. Vitamin ini dapat disintesis di kulit, ada beberapa faktor yang membatasi produksi vitamin D seperti peningkatan pigmentasi di kulit dan tabir surya. Dengan adanya proses penuaan terjadi penurunan kapasitas produksi vitamin $\mathrm{D}$ di kulit. ${ }^{167}$
Pada masa remaja tulang tumbuh dengan cepat, sehingga remaja butuh kalsium sangat banyak. Ketika seseorang mencapai puncak pertumbuhan, kebutuhan kalsium tubuh menjadi stabil. Kalsium pada masa remaja relatif tinggi karena akselerasi muscular, skeletal/kerangka dan perkembangan endokrin lebih besar dibandingkan masa anak dan dewasa. ${ }^{8}$

Hasil penelitian di Yugoslavia terhadap dewasa muda usia 20-23 tahun menunjukkan berat badan dan aktivitas fisik mempunyai pengaruh yang kuat terhadap kadar densitas tulang dibandingkan faktor lainnya seperti diet. ${ }^{9}$ Penelitian pada remaja putri SMAN 3 Semarang usia 15-17 tahun menemukan $18,8 \%$ mengalami densitas tulang rendah dan ada hubungan yang signifikan antara konsumsi protein, kalsium, posfor dan natrium dengan densitas tulang. ${ }^{10}$

SMA Negeri Tilatang Kamang terletak $\pm 7 \mathrm{KM}$ dari pusat kota Bukittinggi. SMA ini didukung oleh akses transportasi yang lancar. SMA Negeri Tilatang Kamang terletak diwilayah kerja Puskesmas Pakan Kamis. Data yang diperoleh, rata-rata orang tua siswi SMAN Tilatang Kamang sebahagian besar adalah petani dan buruh dengan penghasilan dibawah satu juta per bulannya. Kegiatan belajar di SMAN tilatang kamang dimulai pukul 7.30 WIB sampai 14.10 WIB.

Bulan Juni 2015 telah dilakukan penelitian pendahuluan untuk pemeriksaan kepadatan tulang siswi remaja SMAN Tilatang Kamang dengan menggunakan alat sederhana dengan memasukan data jenis kelamin, umur, berat badan, dan tinggi badan. Siswi berdiri di atas alat tersebut kemudian keluar data yang bisa dibaca kepadatan tulangnya. Dari 10 siswi remaja putri yang dijadikan sampel yang diperiksa kepadatan tulangnya 5 orang menunjukan hasil kepadatan tulang yang kurang dan 5 orang lagi menunjukan hasil yang normal.

Ada beberapa faktor risiko yang mempengaruhi kepadatan tulang faktor risiko yang dapat dikendalikan adalah aktivitas fisik, asupan vit $D$ dan kalsium.Dari data yang diperoleh kemungkinan ada hubungan dengan aktivitas fisik serta nutrisi terutama vit $D$ dan kalsium. Berdasarkan hal ini, maka perlu diteliti tentang "Hubungan Tingkat Aktivitas Fisik, Jumlah Asupan Vit D dan Kalsium dengan Tingkat Densitas Tulang Remaja Putri di SMA Negeri Kecamatan Tilatang Kamang Kabupaten Agam Tahun 2016". 


\section{METODE}

Penelitian ini merupakan studi potong lintang (cross sectional study). variabel independen adalah tingkat aktivitas fisik, jumlah asupan vitamin D dan kalsium. Variabel dependen adalah tingkat densitas tulang.

Penelitian ini telah dilaksanakan pada bulan Januari 2015 sampai Oktober 2016 di SMAN 1 dan SMAN 2 yang berlokasi di Kecamatan Tilatang Kamang. Teknik pengambilan sampel dilakukan dengan stratified random sampling, berdasarkan kriteria inklusi dan eksklusi didapatkan total sampel 148 orang. Data primer yang diambil adalah densitas tulang, asupan vitamin D, asupan kalsium,dan aktivitas fisik.

Densitas tulang diukur dengan menggunakan menggunakan alat Quantum Resonance Magnetic Analyzer (QRMA). Aktivitas fisik diperoleh melalui wawancara dengan menggunakan kuisioner Baecke. Data asupan vitamin $\mathrm{D}$ dan kalsium diperoleh melalui wawancara langsung dengan remaja putri dengan menggunakan semi quantitative food frequency questionnaire (SQFFQ) modifikasi masakan minang yang dirancang oleh Lipoeto.
Data sekunder meliputi data gambaran sekolah dan jumlah siswa/i di SMAN 1 dan SMAN 2 Kecamatan Tilatang Kamang. Data ini dikumpulkan dengan mewawancarai pihak sekolah.

Hasil yang didapat dari QRMA, berupa kepadatan tulang dapat dikelompokkan menjadi 2 kategori, yaitu normal jika densitas tulangnya 0,796 0,433; abnormal densitas tulang 0,433-<0,165. Asupan kalsium dikelompokkan menjadi dua kategori, yaitu asupan kurang bila $<80 \%$ AKG dan asupan cukup jika $\geq 80 \%$ AKG. Aktivitas fisik dapat dikategorikan indeks aktivitas kurang aktif jika indeks aktivitas fisik< 7.4 , aktivitas aktif jika indeks aktivitas fisik $\geq 7,4$.

\section{HASIL}

Dalam penelitian ini terdapat beberapa keterbatasan yang menyangkut rancangan dan variabel penelitian. Studi ini menggunakan rancangan penelitian potong lintang (cross sectional study) sehingga tidak memungkinkan untuk menentukan arah hubungan sebab akibat antara variabel independen terhadap variabel dependen. Karakteristik responden secara umum dapat dilihat pada Tabel 1. berikut ini

Tabel 1. Rerata umur, berat badan, tinggi badan dan IMT responden

\begin{tabular}{|c|c|c|c|c|c|}
\hline Variabel & Rerata & Median & SD & Min - Maks & $95 \% \mathrm{Cl}$ \\
\hline Umur (tahun) & 16,3 & 16,0 & 0,9 & $14-19$ & $16,2-16,5$ \\
\hline Berat Badan (kg) & 48,9 & 48,0 & 8,1 & $30,0-75,0$ & $47,6-50,2$ \\
\hline Tinggi Badan (cm) & 156,4 & 156,0 & 6,3 & $131,0-178,0$ & $155,4-157,4$ \\
\hline IMT $\left(\mathrm{kg} / \mathrm{m}^{2}\right)$ & 19,9 & 19,6 & 2,9 & $14,3-29,1$ & $19,5-20,4$ \\
\hline
\end{tabular}

Hasil analisis didapatkan responden berusia minimal 14 tahun maksimal berumur 19 tahun dengan rerata umur 16.3 tahun. Rerata berat badan adalah $48,9 \pm 8,1$ dengan berat minimal $30 \mathrm{~kg}$ dan berat maksimal $75 \mathrm{~kg}$. Rerata tinggi badan $156,4 \pm 6,3 \mathrm{~cm}$, dengan tinggi badan paling rendah $131 \mathrm{~cm}$ dan tinggi badan tertinggi $178 \mathrm{~cm}$. Sedangkan rata-rata IMT responden adalah $19,9 \mathrm{~kg} / \mathrm{m}^{2}$ dengan IMT terendah adalah $14,3 \mathrm{~kg} / \mathrm{m}^{2}$ dan tertinggi $29,1 \mathrm{~kg} / \mathrm{m}^{2}$. Distribusi frekuensi karakteristik responden dapat dilihat pada Tabel 2.

Tabel 2. Rerata asupan vitamin $D$, kalsium dan densitas tulang responden di SMA Negeri 1 dan 2

\begin{tabular}{|c|c|c|c|c|c|}
\hline Variabel & Rerata & Median & SD & Min - Maks & $95 \% \mathrm{Cl}$ \\
\hline Indeks aktivitas fisik & 7,49 & 7,37 & 0,78 & $5,8-9,9$ & $7,37-7,62$ \\
\hline Asupan vitamin D (mcg) & 3,90 & 3,91 & 1,98 & $0,4-9,1$ & $3,58-4,22$ \\
\hline$\%$ Vit. D terhadap AKG & 26,1 & 26,1 & 13,2 & $2,7-60,5$ & $23,9-28,2$ \\
\hline
\end{tabular}


Rerata kadar densitas tulang responden adalah $0,414 \pm 0,214$ dengan kadar terendah 0,167 dan tertinggi 0,788 . Rerata skor indeks aktivitas fisik adalah 7,49 $\pm 0,78$ dengan skor indeks terendah 5,8 dan tertinggi 9,9. Rerata asupan vitamin $D$ responden adalah $3,90 \pm 1,98 \mathrm{mcg}$ dengan nilai terendah $0,4 \mathrm{mcg}$ dan nilai tertinggi 9,1 mcg. Rerata persen asupan vitamin D terhadap Angka Kecukupan Gizi (AKG) yang dianjurkan adalah $26,1 \% \pm 13,2 \%$.

Asupan kalsium rerata responden berada di bawah AKG. Kecukupan kalsium remaja putrid umur
13-15 tahun dan 16-18 tahunmenurut AKG per orang per hari adalah $1200 \mathrm{mg}$, sedangkan umur 19-29 tahun adalah $1100 \mathrm{mg}$. Rerata asupan kalsium responden adalah $882,7 \pm 285,2 \mathrm{mg}$ dan rerata persen asupan kalsium terhadap AKG adalah $73,6 \% \pm$ 23,7\%. Pada Tabel 3, lebih dari separuh (51,4\%) mempunyai tingkat densitas tulang abnormal dan $(48,6 \%)$ densitas tulang yang normal, separuh $(50,7 \%)$ tingkat aktivitas fisiknya kurang aktif dan (49,3\%) mempunyai aktivitas fisik yang aktif, dan lebih dari separuh $(52,7 \%)$ mempunyai asupan kalsium kurang.

Tabel 3. Distribusi frekuensi asupan kalsium, aktivitas fisik dan tingkat densitas tulang responden di SMA Negeri Kecamatang Tilatang Kamang tahun 2016

\begin{tabular}{|c|c|c|}
\hline Variabel & f & $\%$ \\
\hline \multicolumn{3}{|l|}{ Asupan kalsium } \\
\hline Asupan kurang & 78 & 52,7 \\
\hline Asupan cukup & 70 & 47,3 \\
\hline \multicolumn{3}{|l|}{ Tingkat Aktivitas Fisik } \\
\hline Aktivitas kurang aktif & 75 & 50,7 \\
\hline Aktivitas aktif & 73 & 49,3 \\
\hline \multicolumn{3}{|l|}{ Tingkat Densitas tulang } \\
\hline Abnormal & 76 & 51,4 \\
\hline Normal & 72 & 48,6 \\
\hline Jumlah & 148 & 100,0 \\
\hline
\end{tabular}

Tabel 4. Hubungan tingkat aktivitas fisik dengan tingkat densitas tulang remaja putri di SMA Negeri Kecamatang Tilatang Kamang tahun 2016

\begin{tabular}{|c|c|c|c|c|c|c|c|c|}
\hline \multirow{3}{*}{ Tingkat Aktivitas Fisik } & \multicolumn{4}{|c|}{ Tingkat Densitas Tulang } & \multirow{2}{*}{ Jumla } & \multirow{2}{*}{\multicolumn{3}{|c|}{$\begin{array}{c}\text { OR } \\
(95 \% \mathrm{Cl})\end{array}$}} \\
\hline & \multicolumn{2}{|c|}{ Abnormal } & \multicolumn{2}{|c|}{ Normal } & & & & \\
\hline & $f$ & $\%$ & $\mathbf{f}$ & $\%$ & $\mathbf{f}$ & $\%$ & & \\
\hline Kurang aktif & 65 & 86,7 & 10 & 13,3 & 75 & 100,0 & 36,64 & חמת ח \\
\hline Aktif & 11 & 15,1 & 62 & 84,9 & 73 & 100,0 & $14,5-92,3$ & 0,000 \\
\hline Jumlah & 76 & 51,4 & 72 & 48,6 & 148 & 100,0 & & \\
\hline
\end{tabular}

Berdasarkan Tabel 4 diketahui bahwa tingkat densitas tulang abnormal persentasenya lebih tinggi pada responden dengan aktivitas fisik kurang aktif $(86,7 \%)$ dibanding dengan aktivitas fisik aktif $(15,1 \%)$. Hasil uji secara statistik antara tingkat aktivitas fisik dengan tingkat densitas tulang remaja putri diperoleh nilai $p<0,05$, yang berarti ada hubungan bermakna antara tingkat aktivitas fisik dengan tingkat densitas tulang remaja putri, dimana remaja putri dengan aktivitas fisik kurang aktif mempunyai peluang 36,64 kali memiliki tingkat densitas tulang abnormal dibanding remaja putri dengan aktivitas fisik aktif.

Hasil penelitian ini menunjukkan semua responden mempunyai asupan vitamin $\mathrm{D}$ yang kurang dari angka kecukupan gizi yang dianjurkan. Hubungan asupan vitamin $D$ dengan tingkat densitas tulang dianalisis dengan uji statistik korelasi dan regresi linier. 


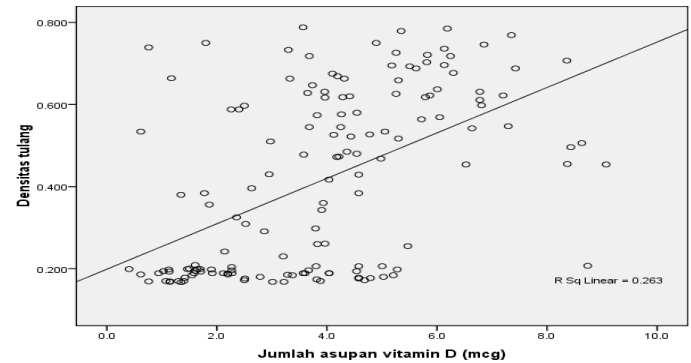

Gambar 1. Hubungan asupan vitamin D dengan tingkat densitas tulang.
Hubungan asupan vitamin D dengan tingkat densitas tulang menunjukan hubungan yang kuat $(r=0,513)$ dan berpola positif artinya semakin tinggi asupan vitamin D semakin tinggi tingkat densitas tulang. Hasil uji statistik yang didapatkan ada hubungan yang signifikan antara asupan vitamin $D$ dengan densitas tulang F1, 147=52.138 $(p=0,000)$.

Tabel 5. Hubungan asupan kalsium dengan tingkat densitas tulang remaja putri di SMA Negeri Kecamatang Tilatang Kamang tahun 2016.

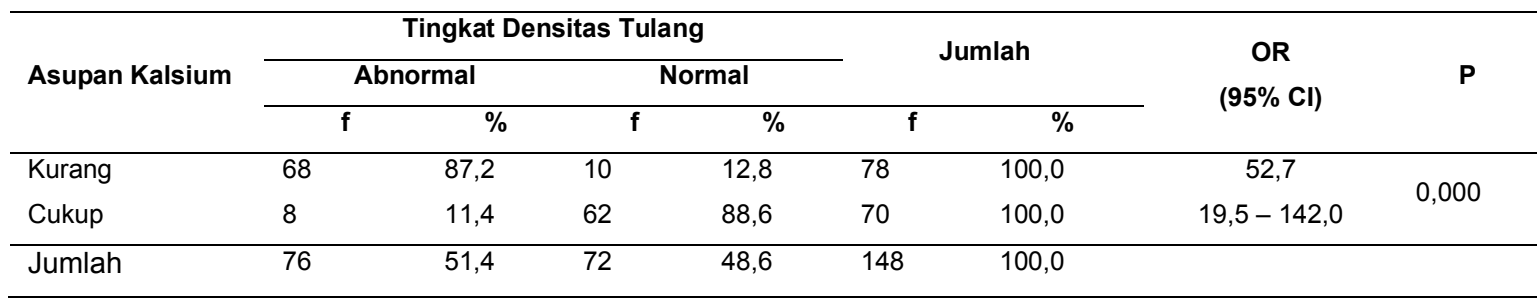

Tabel 5 menunjukkan bahwa tingkat densitas tulang abnormal persentasenya lebih tinggi pada responden dengan asupan kalsium kurang $(87,2 \%)$ dibanding dengan asupan kalsium cukup $(11,4 \%)$. Hasil uji secara statistik antara asupan kalsium dan tingkat densitas tulang remaja putri diperoleh nilai $p<$ 0,05 , yang berarti ada hubungan bermakna antara asupan kalsium dengan tingkat densitas tulang remaja putri, dimana remaja putri dengan asupan kalsium kurang mempunyai peluang 52,7 kali memiliki tingkat densitas tulang abnormal dibanding remaja putri dengan asupan kalsium cukup.

\section{PEMBAHASAN}

Desain penelitian ini adalah studi potong lintang (cross sectional study) pada remaja putri di SMA Negeri Kecamatan Tilatang Kamang. Ada beberapa keterbatasan yang menyangkut rancangan dan variabel penelitian. Penelitian ini menggunakan rancangan penelitian potong lintang (cross sectional study) sehingga tidak memungkinkan untuk menentukan arah hubungan sebab akibat antara variabel independen terhadap variabel dependen. Hal ini disebabkan kedua variabel tersebut diukur pada saat yang sama sehingga sulit menentukan variabel mana yang terjadi terlebih dahulu.
Banyak faktor yang berhubungan dengan tingkat densitas tulang remaja putri, tetapi karena keterbatasan yang dimiliki, maka penelitian ini hanya meneliti beberapa variabel yang berhubungan dengan tingkat densitas tulang seperti yang tercantum pada kerangka konsep.

Asupan vitamin $D$ dan kalsium menggunakan metode Semi Quantitative Food Frequency Questionare (SQFFQ) modifikasi masakan minang yang dirancang Lipoeto. FFQ ini masih ada kekurangan dan perlunya perbaikan karna masih adanya bahan masakan yang belum termasuk didalam kuesioner seperti jamur, jengkol, petai serta olahannya, sayuran buncis, pare, oyong serta olahannya. Untuk memperoleh data asupan vitamin D dan kalsium yang benar tergantung pada kemampuan responden, motivasi, kesadaran akan asupan pangan, ingatan (mengingat pola makan, jenis dan jumlah makanan masa lalu) dan kemampuan berkomunikasi memberikan data konsumsi makanan yang benar.

Hasil penelitian diperoleh asupan vitamin D semua responden kurang dari Angka Kecukupan Gizi (AKG) yaitu kurang dari $15 \mathrm{mcg}$. Hubungan asupan vitamin $\mathrm{D}$ dengan densitas tulang diuji dengan statistik korelasi dan regresi linier. 
Pada penelitian ini didapatkan densitas tulang sampel adalah 0,414 $\pm 0,214$ dan lebih dari separuh $(51,4 \%)$ mempunyai tingkat densitas tulang abnormal. Densitas atau kepadatan tulang adalah rasio massa tulang dengan volume, menunjukkan kekompakan tulang. Densitas massa tulang berhubungan dengan kekuatan tulang dan resiko fraktur., 2,11,12

Tingkat densitas tulang dapat dikelompokkan menjadi 2 kategori, yaitu normal jika tingkat densitas tulangnya 0,796 - 0,433; abnormal jika densitas tulangnya $0,433-<0,165$. Bila dibandingkan dengan penelitian Meikawati dan Amelia (2010) angka yang didapatkan pada penelitian ini lebih tinggi yaitu 18,8\% remaja putri SMAN 3 Semarang usia 15-17 tahun mengalami densitas tulang rendah $^{10 .}$ Sedangkan penelitian Karlina (2011) menemukan 66,7\% remaja putri di Asrama Tingkat Persiapan Bersama (TPB) Institut Pertanian Bogor mempunyai densitas tulang di bawah rata-rata ${ }^{13}$.

Puncak massa tulang dicapai pada usia 20-30 tahun. Berkurangnya massa tulang mulai terjadi setelah usia 30 tahun yang akan makin bertambah setelah usia 40 tahun dan akan berlangsung terus dengan bertambahnya usia. ${ }^{10}$.

Pada penelitian ini ditemukan proporsi responden dengan tingkat aktivitas fisik kurang aktif separuh $(50,7 \%)$ dan tingkat aktivitas fisik aktif (49.3\%). Proporsi aktivitas fisik kurang aktif yang ditemukan pada penelitian ini tidak berbeda jauh dengan penelitian Nizar (2009) yaitu aktvitas fisik ringan sebesar $58,2 \%$ pada remaja putri di SMAN Kota Padang. ${ }^{14}$ Namun lebih rendah dibandingkan dengan penelitian yang dilakukan oleh Fikawati et al (2005) pada remaja di Kota Bandung menemukan bahwa sebagian besar $(84,4 \%)$ remaja memiliki tingkat aktivitas fisik kurang aktif ${ }^{15}$.

Aktivitas fisik pada penelitian ini dapat dilihat di kalangan remaja putri masih kurang aktif. Pada remaja awal pelajaran, di sekolah tidak terlalu padat sehingga waktu luang dapat digunakan untuk olahraga. Namun pada jenjang yang lebih tinggi pelajaran semakin padat sehingga tidak mendapatkan waktu yang cukup untuk berolah raga. Era alat elektronik yang makin canggih sekarang ini menonton TV, bermain video games dan bermain Ipad secara tidak langsung mengurangi kesempatan remaja berada di luar rumah sehingga akan mengurangi kesempatan untuk beraktivitas fisik. Faktor musim dan cuaca juga berperan terhadap aktivitas fisik remaja. Remaja berada di luar rumah melakukan aktivitas fisik lebih tinggi pada musim panas, tetapi menurun pada musim hujan. ${ }^{16}$

Aktivitas fisik mempengaruhi massa tulang terutama latihan beban. Jika tidak ada tekanan pada tulang, tulang akan bereaksi dengan memasuki proses resorbsi dan siklus kegiatan tulang ini akan berakibat jaringan tulang dengan bahaya lanjutan berupa osteoporosis ${ }^{17}$.

Hasil penelitian ini menunjukkan bahwa ratarata asupan vitamin $D$ responden adalah $3,90 \pm 1,98$ mcg dengan asupan terendah 0,4 mcg dan asupan tertinggi $9,1 \mathrm{mcg}$. Asupan vitamin D per harinya hanya mencapai $26,1 \%$ dengan standar deviasi $13,2 \%$ dari Angka Kecukupan Gizi (AKG) yang dianjurkan.

Hal yang sama dikemukan oleh Cannel et all (2008) bahwa konsumsi pangan secara normal mengandung sedikit sumber vitamin $D$ kecuali mereka yang makan ikan yang mengandung tinggi lemak. Sumber vitamin $\mathrm{D}$ juga bisa didapat dari makanan yang difortifikasi seperti susu, jus jeruk, sereal dan margarin. ${ }^{18}$

Kelompok makanan yang menyumbangkan asupan vitamin D paling besar antara lain ikan, kerang, udang, dan telur. Hasil ini sama dengan yang dinyatakan oleh Bowden et al (2008) dan Persagi (2009) pada umumnya pangan sumber vitamin D adalah ikan dan telur. Kecukupan vitamin $D$ dalam tubuh diharapkan mampu membantu metabolisme tulang, mengatur homeostatis kalsium plasma, meningkatkan absorpsi kalsium dan fosfat melalui usus halus 51920

Hasil penelitian ini dapat disimpulkan bahwa vitamin $\mathrm{D}$ penting untuk pembentukan tulang karena membantu dalam meningkatkan absorbsi kalsium dari saluran pencernaan dan untuk menyimpan kalsium bersama fosfat di dalam kerangka tubuh. Selain dari makanan, vitamin $D$ juga dapat diperoleh dari pemaparan kulit terhadap sinar matahari yamg mengubah vitamin D3 yang ada pada kulit menjadi senyawa 1,25-dehidro-kolekalsiferol sehingga dapat 
meningkatkan penyerapan kalsium dari usus. Produksi vitamin D pada kulit cukup cepat setelah beberapa menit terpapar dengan sinar matahari. ${ }^{21}$

Hasil penelitian memperlihatkan bahwa asupan kalsium rata-rata responden berada di bawah Angka Kecukupan Gizi (AKG) yang dianjurkan yaitu 73,6\% dengan standar deviasi $23,7 \%$. Rata-rata asupan kalsium responden adalah $882,7 \pm 285,2 \mathrm{mcg}$. Lebih dari separuh $(52,7 \%)$ responden mempunyai asupan kalsium kurang.

Pada masa remaja dengan pertumbuhannya yang pesat sangat dibutuhkan energi yang cukup, zatzat gizi lain yang khususnya perlu mendapat perhatian adalah protein, mineral dan vitamin. Banyak studi gizi menyatakan bahwa untuk remaja kecukupan gizi tidak hanya ditentukan oleh umur saja tetapi jug oleh tahap dan perkembangan kematangan fisiknya. Pada remaja yang berada pada puncak pertumbuhan fisiknya akan membutuhkan dua kali lipat kalsium, zatbesi, seng, magnesium dan nitrogen. ${ }^{22}$

Berdasarkan hasil penelitian sebelumnya menunjukkan hasil yang tidak jauh berbeda, yaitu rata-rata asupan kalsium remaja masih kurang dari angka kecukupan gizi yang dianjurkan (AKG). Kebutuhan kalsium remaja usia 13-18 tahun $1200 \mathrm{mg}$ kalsium setiap hari, usia 19-29 tahun $1100 \mathrm{mg}$ kalsium setiap hari. ${ }^{23}$

Hasil penelitian ini menunjukkan ada hubungan bermakna antara tingkat aktivitas fisik dengan tingkat densitas tulang remaja putri. Remaja putri dengan aktivitas fisik kurang aktif mempunyai peluang 36,64 kali memiliki tingkat densitas tulang abnormal dibanding remaja putri dengan aktivitas fisik aktif.

Hasil penelitian ini juga dibuktikan dengan penelitian pada anak-anak dan remaja usia 5-19 tahun di Denmark menemukan asupan kalsium dan aktivitas fisik mempunyai hubungan positif dengan densitas tulang. ${ }^{24}$

Latihan fisik yang teratur akan memberikan efek terapi yang menguntungkan dalam pengobatan dari berbagai penyakit seperti gangguan sindrom metabolik (resistensi insulin, diabetes tipe 1, diabetes tipe 2 dislipidemia, hipertensi, obesitas), penyakit jantung (penyakit jantung korener, gagal jantung kronis), penyakit paru (penyakit paru obstruktif kronik), kanker, depresi, penyakit otot, penyakit sendi (osteoarthritis, rheumatoid arthtritis), penyakit tulang (osteoporosis). ${ }^{25}$

Indek aktivitas fisik merupakan aktivitas seharihari yang meliputi indek kegiatan waktu bekerja, indek kegiatan olahraga,indek kegiatan waktu luang. ${ }^{26}$ Perubahan tulang yang disebabkan oleh aktivitas fisik dapat meningkatkan enzim tulang dan pembesaran pada tulang (bonehypertrophy). Untuk pembentukan tulang baru diperlukan rangsangan terus menerus pada tulang. Aktivitas fisik juga dibutuhkan untuk penambahan kepadatan tulang. Tulang kita seperti otot perlu latihan supaya kuat. Sejak dini seseorang harus tetap aktif bergerak, baik itu dalam bentuk olahraga, latihan fisik maupun dalam kegiatan sehari-hari ${ }^{1}$.

\section{Hubungan Asupan Vitamin D dengan Densitas Tulang}

Hubungan asupan vitamin $D$ dengan densitas tulang menunjukan hubungan yang kuat $(r=0,513)$ dan berpola positif artinya semakin tinggi asupan vitamin $D$ semakin tinggi kadar mineral tulang. Vitamin D berfungsi dalam pertumbuhan tulang normal dan proses mineralisasi. Vitamin $D$ mempengaruhi metabolisme kalsium. Vitamin D dapat disintesis di kulit, ada beberapa faktor yang membatasi produksi vitamin D seperti peningkatan pigmentasi di kulit dan tabir surya. Dengan adanya proses penuaan terjadi penurunan kapasitas produksi vitamin $\mathrm{D}$ di kulit. Pada orang kulit berwarna produksi vitamin D oleh kulit juga berkurang, karena melanin merupakan penahan sinar matahari yang sangat baik begitu juga terhadap orang yang memakai tabir surya (sun block). Paparan sinar matahari pukul 6-9 pagi dan pukul 4 sore pada lengan bawah dan wajah selama 5-30 menit. 1-3 kali seminggu direkomendasikan untuk memenuhi kebutuhan vitamin D di kulit. Penduduk di daerah tropik tidak perlu khawatir karena sinar matahari terdapat sepanjang hari. ${ }^{1,6,7}$

Hasil uji secara statistik menemukan ada hubungan bermakna antara asupan kalsium dengan tingkat densitas tulang remaja putri, dimana remaja putri dengan asupan kalsium kurang mempunyai peluang 52,7 kali memiliki tingkat densitas tulang abnormal dibanding asupan kalsium cukup. 
Penelitian ini sejalan dengan penelitian Hardiansyah et al (2008) pada remaja di SMAN Bogor serta Meikawati dan Amelia (2010) pada remaja putri SMAN 3 Semarang menemukan ada hubungan asupan kalsium dengan densitas tulang. Hasil survey memperlihatkan bahwa intake mineral terutama kalsium dan fe pada remaja masih kurang. ${ }^{1027}$

Semakin tinggi kebutuhan dan semakin rendah persediaan kalsium dalam tubuh semakin efisien absorpsi kalsium. Jumlah kalsium yang dikonsumsi mempengaruhi absorpsi kalsium. Penyerapan akan meningkat bila kalsium yang dikonsumsi menurun. Vitamin $D$ dan aktivitas fisik berpengaruh baik terhadap absorpsi kalsium. ${ }^{6}$

Konsumsi kalsium pada masyarakat miskin di Asia masih sangat rendah dibawah kecukupan yang dianjurkan, yaitu hanya $300 \mathrm{mg} / \mathrm{hari}$. Hasil survey konsumsi memperlihatkan bahwa asupan mineral terutama kalsium dan Fe pada remaja masih kurang. Hal ini disebabkan oleh perilaku makan mereka yang memilih makanan populer seperti fast food biasanya mengandung zat gizi yang terbatas atau rendah sedangkan kandungan lemak dan natriumnya cukup tinggi. $^{8,28}$

\section{SIMPULAN}

Terdapat hubungan yang bermakna antara aktivitas fisk dengan densitas tulang dan asupan vitamin $\mathrm{D}$, kalsium dengan densitas tulang.

\section{SARAN}

Menganjurkan kepada kelompok responden untuk meningkatkan aktivitas fisik terutama olahraga yang bersifat pembebanan seperti melompat untuk menambah kepadatan tulang, makan makanan yang tinggi vitamin $D$ serta menganjurkan untuk keluar rumah agar terpapar sinar matahari terutama pukul 69 pagi dan pukul 4 sore pada lengan bawah dan wajah selama 5-30 menit 1-3 kali seminggu untuk mendapatkan vitamin $D$ yang disitesis di kulit. Dianjurkan untuk mengkonsumsi kalsium yang banyak terdapat pada susu dan olahannya. Minum susu pada malam hari karna aktivitas tubuh kosong sehingga tubuh dapat menyerap secara optimal.

\section{UCAPAN TERIMA KASIH}

Terimakasih kepada semua pihak yang telah memberikan bimbingan, arahan, saran dan masukan dalam penelitian ini.

\section{DAFTAR PUSTAKA}

1. Wiarto G. Fisiologi dan olahraga. Yogyakarta: Graha IImu; 2013.

2. Setiyohadi B. Struktur dan metabolism tulang. Dalam: Aru W, Sudoyo, Setiyohadi B, Alwi I, Marcellus S, Setiati S, editor (penyunting). Buku ajar ilmu penyakit dalam. Edisi ke-4. Jakarta: Pusat Penerbitan IImu Penyakit Dalam Fakultas Kedokteran Universitas Indonesia; 2010. hlm.1096106.

3. Gibney, Michael J, Barrie M, Margetts, John M, Kearney, Lenore, A. Gizi kesehatan masyarakat. Hartono A, penerjemah. Jakarta. EGC. Terje mahan dari: Public Health Nutrition. 2009.

4. Afriwardi. IImu kedokteran olahraga. Jakarta: EGC; 2011.

5. Almatsier S. Prinsip dasar ilmu gizi. Jakarta: Gramedia Pustaka Utama; 2006.

6. Wirakusumah E. Mencegah osteoporosis lengkap dengan 39 jus dan 38 resep makanan. Jakarta: Penebar Plus; 2007.

7. Kertia N. Osteomalasia. Dalam: Aru W, Sudoyo, Setiyohadi B, Alwi I, Marcellus S, Setiati S, editor (penyunting). Buku ajar ilmu penyakit dalam. Edisi ke-4. Jakarta: Pusat Penerbitan IImu Penyakit Dalam Fakultas Kedokteran Universitas Indonesia. 2010. hlm.1275-6.

8. Syafiq A, Setiarini A, Laksminingsih, Endang. Gizi dan kesehatan masyarakat. Jakarta; PT Raja Grafindo Persada; 2007.

9. Fehily AM, Coles RJ, Evans WD, Elwood PC. Factors affecting bone density in young adults. Am J ClinNutr. 1992;56:3579-86.

10. Meikawati W, Amelia, R. Faktor yang berhubungan kepadatan tulang remaja. Semarang. Prosiding Seminar Nasional Unimus Journal of Nutrition College. 2010;192-7.

11. Compston J. Osteoporosis. Clinikal Endocrinology. 1990;33(5):653-82. 
12. Tandra H. Segala sesuatu yang harus anda ketahui tentang osteoporosis mengenal, mengatasi, dan mencegah tulang keropos. Jakarta: Gramedia Pustaka Utama; 2009.

13. Karlina. Hubungan konsumsi susu dan kebiasaan olahraga dengan status gizi dan densitas tulang remaja di asrama Tingkat Persiapan Bersama (TPB) (skripsi). Bogor: Departemen gizi Masyarakat Fakultas Ekologi Manusia Institut Pertanian Bogor; 2011.

14. Nizar M. Analisis faktor-faktor yang berhubungan dengan konsumsi kalsium remaja putri di Kota Padang Propinsi Sumatera Barat tahun 2009. Jurnal Sehat Mandiri. 2009;4(2):188-99.

15. Fikawati S, Syafiq A, Puspasari P. Konsumsi kalsium pada remaja, gizi dan kesehatan masyarakat. Jakarta: Depertemen Gizi dan Kesehatan Masyarakat Universitas Indonesia. PT .Raja Grafindo Persada; 2005.

16. Klesges RC, Eck LH, Hanson CL, Haddock, CK, Klesges LM. Effect of obesity, social interactions and physical environment on physical activity inpreschoolers. Health Psychol.1990;9(4):435-49.

17. Gomez J. Awas pengeroposan tulang bagaimana menghindari dan menghadapi.Jakarta.Arcan. 2006.

18. Cannell JJ, Hollis BW, Zasloff M, Heaney. Diagnosis and treatment of vitamin $\mathrm{D}$ deficiency. Expert Opin Pharmacother. 2008;9(1):107-18.

19. Bowden SA, Robinson RF, Carr R, Mahan JD. Prevalence of vitamin $D$ deficiency and insufficiency in children with osteopenia or osteoporosis referred to a pediatric metabolic bone clinic. Pediatrics. 2008;121:e1585-90.
20. Persagi. Kamus gizi: pelengkap kesehatan keluarga. Jakarta: Kompas; 2009.

21. Hughes B, Harris SS, Kral EA, Dallal GE. Effect of calcium and vitamin $D$ supplementation on bone density in men and women 65 years of age or older. N Engl J Med 337. 1997;(10):670-6.

22. Suhardjo. Pangan, gizi dan pertanian. Jakarta. UI Press. 1986.hlm.258.

23. Kementrian Kesehatan Republik Indonesia. Angka kecukupan gizi yang dianjurkan bagi bangsa Indonesia. Jakarta: Kementrian Kesehatan Republik Indonesia; 2013.

24. Molgaard C, Michaelsson K. The influence of calcium intake and physical activity on bone mineral content and bone size in healthy children and adolescents. Denmark. International Osteoporosis Foundation and National Osteoporosis Foundation. 2001.hlm.887-94.

25. Pedersen BK, Saltin B. Evidence for prescribing exercise as therapy in chronic disease. Scand $\mathrm{J}$ Med Sci Sports. 200616(Suppl.1):3-63.

26. Baecke J, Burema J, Frijter J. A short questionnaire for the measurement of habitual physical activity in epidemiological studies. Am.J. Clin.Nutr.1982;36:936-42.

27. Hardiansyah, Damayanthy E, Zulianti W. Hubungan konsumsi susu dan kalsium dengan densitas tulang dan tinggi badan remaja. Jurnal gizi dan panagan. 2008;3(1):43-8.

28. Gopalan C. Nutrition research in South East Asia, the emerging agenda of the future. Regional Puplication, SEARO. 1994;23:1-135. 